\title{
Molecular mechanisms of long noncoding RNAs on gastric cancer
}

\author{
Tianwen $\mathrm{Li}^{1}$, Xiaoyan Mo ${ }^{1}$, Liyun $\mathrm{Fu}^{1,2}$, Bingxiu Xiao ${ }^{1}$ and Junming Guo ${ }^{1}$ \\ ${ }^{1}$ Department of Biochemistry and Molecular Biology, and Zhejiang Key Laboratory of Pathophysiology, Ningbo University \\ School of Medicine, Ningbo, China \\ 2 Department of Hepatology, Ningbo No.2 Hospital, Ningbo, China
}

Correspondence to: Junming Guo, email: junmingguo@yahoo.com

Keywords: IncRNA, gastric cancer, miRNA, ceRNA, gene expression

Received: October 18, $2015 \quad$ Accepted: January 13, 2016

Published: January 17, 2016

\section{ABSTRACT}

Long noncoding RNAs (IncRNAs) are non-protein coding transcripts longer than 200 nucleotides. Aberrant expression of IncRNAs has been found associated with gastric cancer, one of the most malignant tumors. By complementary base pairing with mRNAs or forming complexes with RNA binding proteins (RBPs), some IncRNAs including GHET1, MALAT1, and TINCR may mediate mRNA stability and splicing. Other IncRNAs, such as BC032469, GAPLINC, and HOTAIR, participate in the competing endogenous RNA (ceRNA) network. Under certain circumstances, ANRIL, GACAT3, H19, MEG3, and TUSC7 exhibit their biological roles by associating with microRNAs (miRNAs). By recruiting histone-modifying complexes, ANRIL, FENDRR, H19, HOTAIR, MALAT1, and PVT1 may inhibit the transcription of target genes in cis or trans. Through these mechanisms, IncRNAs form RNA-dsDNA triplex. CCAT1, GAPLINC, GAS5, H19, MEG3, and TUSC7 play oncogenic or tumor suppressor roles by correlated with tumor suppressor P53 or onco-protein c-Myc, respectively. In conclusion, interaction with DNA, RNA and proteins is involved in IncRNAs' participation in gastric tumorigenesis and development.

\section{INTRODUCTION}

Generally defined as transcripts longer than 200 nucleotides, long noncoding RNAs (lncRNAs) are lack of significant open reading frames [1]. According to their location and orientation, lncRNAs are classified as intergenic lncRNAs (lincRNAs), genic and intragenic lncRNAs [2]. In nucleus, lncRNAs mainly modulate gene transcription and mRNA splicing; while they impact RNA stability and microRNA (miRNA) activity in cytoplasm [3].

Among the malignant tumors, gastric cancer remains the fourth most prevalent one and the second leading mortality [4]. Over the last decade, remarkable progresses about gastric cancer-associated lncRNAs have been achieved. LncRNAs are involved in several tumor signaling pathways such as Notch, mTOR, NF$\kappa b$, and Wnt $[5,6]$. They manipulate cell proliferation, migration, apoptosis, invasion, tumorigenicity, cell cycle, and metastasis (Table 1). Besides, accumulated evidences suggest that the aberrant expressions of lncRNAs have clinical significances in gastric cancer diagnosis [7-17]. They are associated with clinicopathological factors including metastasis, invasion, TNM stage, prognosis, tumor size, and differentiation of patients with gastric cancer (Table 2). Among them, the most proportion are involved in metastasis and invasion $(61.70 \%$ and $53.19 \%$, respectively). These gastric cancer-associated lncRNAs may be used as biomarkers for indicating metastasis of gastric cancer [18-24].

In this article, we summarized the molecular mechanisms of lncRNAs on gastric cancer. By interacting with DNA, RNA, and proteins, IncRNAs play crucial roles in gastric tumorigenesis and development.

\section{INTERACTION WITH DNA}

LncRNAs may combine with histone-modifying complexes and then target on DNA [25]. For example, combining with histone-modifying complexes, forkhead box F1 (FOXF1) adjacent non-coding developmental regulatory RNA (FENDRR) anchors to targeted promoter fragments [26]. HOX transcript antisense RNA (HOTAIR) also occupies targeted double-strained DNA (dsDNA) [27]. Additionally, the lncRNA transcribed from the minor promoter of the human dihydrofolate reductase (DHFR) 
gene combines with the key regulatory region of its host gene in a triple helical model [28]. These triplex structures can be served as a specific recognition mechanism between lncRNA and genomic DNA. Theoretically, these are involved in specificities and affinities. Triplexes created by lncRNA and genomic DNA may decisively result in targeting specificity. Favorable chromatin conformation may contribute to the affinity [29].

\section{INTERACTION WITH RNA}

\section{Interaction with mRNA}

The base paring is formed between protein-coding transcript and the complementary lncRNA, the natural antisense transcript (NAT). Interestingly, the RNA duplex may be created by incompletely base pairing between Alu elements in a targeted mRNA and the complementary sequence harbored in an lncRNA. Staufen 1 (STAU1)

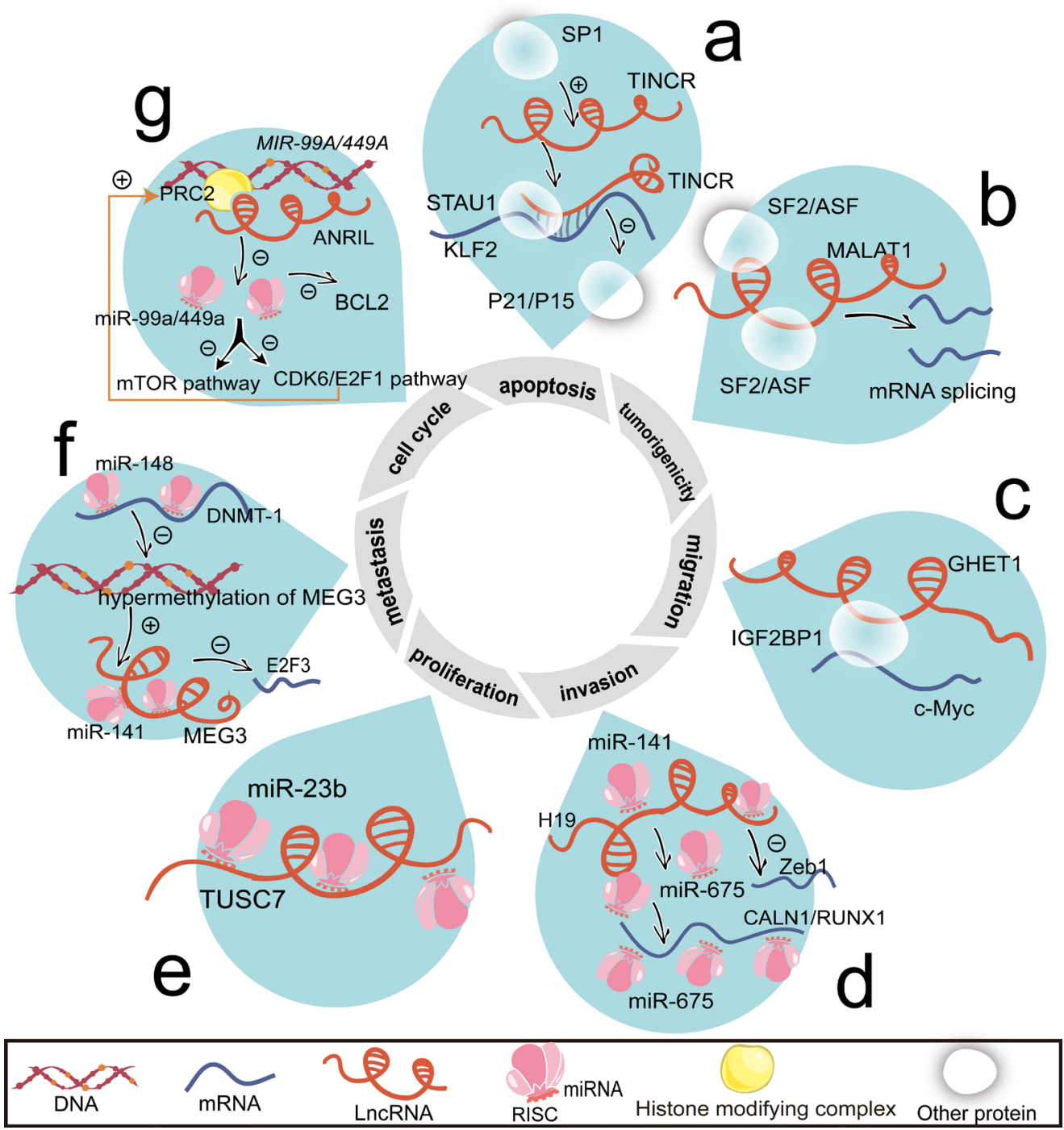

Figure 1: Associated with mRNAs and miRNAs, IncRNAs regulate cell proliferation, cell cycle, apoptosis, invasion, migration, metastasis, and tumorigenicity. a. Induced by SP1, TINCR duplexes with KLF2 mRNA. STAU1 recognizes the double strained RNA and accelerates KLF2 mRNA degradation. Then, KLF2 transcriptionally activates P21/P15 and elevates protein levels of P21/P15. b. MALAT1 changes the distribution of SF2/ASF and then indirectly influences mRNA splicing. c. By binding to IGF2BP1, GHET1 promotes c-Myc mRNA stability. d. By binding with miR-141, H19 inhibits ZEB1 mRNA level. H19 also generates to miR-675, which suppresses the expression of CALN1 and RUNX1. e. TUSC7 is a negative target of miR-23b. f. miR-148a negatively regulates DNMT-1 expression, thus reducing the hypermethylation of MEG3 promoter region. Loss of hypermethylation enhances the transcription of MEG3. Through direct interacting with miR-141, MEG3 downregulates E2F3 mRNA expression. g. By epigenetically silencing MIR49A/MIR-449A, ANRIL promotes mTOR and CDK6/E2F1 pathway that feedback enhances ANRIL expression. And miR-449a inhibits BCL2 expression. Abbreviations: CALN1, calneuron 1; E2F3, E2F transcription factor 3; mTOR, mechanistic target of rapamycin; P15, cyclin-dependent kinase inhibitor 2B; RUNX1, runt domain transcription factor 1; SP1, nuclear transcription factor. 
Table 1: Roles of IncRNAs in gastric cancer cells

\begin{tabular}{|l|l|l|l|}
\hline Function & LncRNAs & Number & Percentage (\%) \\
\hline Proliferation & $\begin{array}{l}\text { ANRIL, BC032469, CCAT1, FENDRR, GAPLINC, GAS5, } \\
\text { GHET1, H19, HOTAIR, LEIGC, Linc00152, LSINCT5, } \\
\text { MALAT1, MEG3, nc886, PVT1, SPRY4-IT1, TINCR, TUSC7, } \\
\text { UBC1, UCA1 }\end{array}$ & 72.41 \\
\hline Migration & $\begin{array}{l}\text { BC032469, CCAT1, FENDRR, FRLnc1, H19, HOTAIR, HULC, } \\
\text { LEIGC, Linc00152, MALAT2, SDMGC, SPRY4-IT1, UBC1 }\end{array}$ & 13 & 44.83 \\
\hline Apoptosis & $\begin{array}{l}\text { ANRIL, CCAT1, GAS5, H19, HOTAIR, HULC, Linc00152, } \\
\text { MEG3, nc886, PVT1, TINCR }\end{array}$ & 37.93 \\
\hline Invasion & $\begin{array}{l}\text { ATB, FENDRR, GAPLINC, H19, HOTAIR, HULC, Linc00152, } \\
\text { SDMGC, SPRY4-IT1, UBC1 }\end{array}$ & 10 & 34.48 \\
\hline Tumorigenicity & $\begin{array}{l}\text { ANRIL, BC032469, GAS5, GHET1, H19, HOTAIR, LEIGC, } \\
\text { PVT1, TINCR }\end{array}$ & 9 & 31.03 \\
\hline Cell cycle & $\begin{array}{l}\text { AC130710, CCAT1, GAS5, Linc00152, MALAT1, MEG3, } \\
\text { PVT1, TINCR }\end{array}$ & 8 & 27.59 \\
\hline Metastasis & FENDRR, FRLnc1, H19 & 3 & 10.34 \\
\hline Total & & 29 & 100 \\
\hline
\end{tabular}

Table 2: LncRNAs and their clinical association of patients with gastric cancer

\begin{tabular}{|c|c|c|c|}
\hline Clinicopathological factor & LncRNAs & Number & Percentage $(\%)$ \\
\hline Metastasis & $\begin{array}{l}\text { AA174084, AC096655.1-002, AC130710, BANCR, } \\
\text { CCAT1, CCAT2, FENDRR, FER1L4, FRLnc1, GACAT2, } \\
\text { GACAT3, GAPLINC, GAS5, H19, HIF1A-AS2, HOTAIR, } \\
\text { HULC, LET, LSINCT5, MALAT1, MALAT2, ncRuAR, } \\
\text { RP11-789C1.1, SPRY4-IT1, SUMO1P3, TINCR, UBC1, } \\
\text { XLOC 010235, ZMAT1 transcript variant 2 }\end{array}$ & 29 & 61.70 \\
\hline Invasion & $\begin{array}{l}\text { AA174084, AI364715, ATB, BANCR, CCAT1, FENDRR, } \\
\text { FER1L4, GACAT2, GAS5, GHET1, H19, HIF1A-AS2, } \\
\text { HOTAIR, LET, Linc00152, LSINCT5, MEG3, ncRuAR, } \\
\text { PVT1, SPRY4-IT1, SUMO1P3, TINCR, TUSC7, UCA1, } \\
\text { ZMAT1 transcript variant 2 }\end{array}$ & 25 & 53.19 \\
\hline TNM stage & $\begin{array}{l}\text { AC096655.1-002, AC130710, BANCR, BM7402401, } \\
\text { CCAT1, FENDRR, FER1L4, GACAT3, GAS5, H19, } \\
\text { HIF1A-AS2, HOTAIR, HULC, LET, LSINCT5, MEG3, } \\
\text { PVT1, RP11-789C1.1, SPRY4-IT1, TINCR, UBC1, UCA1, } \\
\text { XLOC_010235, ZMAT1 transcript variant 2 }\end{array}$ & 24 & 51.06 \\
\hline Prognosis & $\begin{array}{l}\text { AC138128.1, ATB, BANCR, BM7402401, CCAT2, } \\
\text { DRAIC, FENDRR, GAS5, GHET1, H19, HIF1A-AS2, } \\
\text { HOTAIR, LET, LSINCT5, MALAT2, MEG3, PVT1, RP11- } \\
\text { 789C1.1, SPRY4-IT1, TINCR, UBC1, XLOC_010235, } \\
\text { ZMAT1 transcript variant 2 }\end{array}$ & 23 & 48.94 \\
\hline Tumor size & $\begin{array}{l}\text { AC130710, AI364715, CCAT1, DKFZP434K028, } \\
\text { FER1L4, GACAT3, GAPLINC, GAS5, GHET1, HOTAIR, } \\
\text { Linc00152, LSINCT5, MEG3, ncRuAR, RPL34-AS1, } \\
\text { SPRY4-IT1, SUMO1P3, UBC1, UCA1 }\end{array}$ & 19 & 40.43 \\
\hline Differentiation & $\begin{array}{l}\text { ABHD11-AS1, AC096655.1-002, AI364715, HOTAIR, } \\
\text { SUMO1P3, TUSC7, UCA1 }\end{array}$ & 7 & 14.89 \\
\hline Total & & 47 & 100 \\
\hline
\end{tabular}

protein recognizes the dsRNA binding sites and then results in mRNA degradation. This type of lncRNAs is called 1/2-STAU1-binding site RNAs [30]. And the process is termed as staufen-mediated mRNA decay (SMD) [31]. For instance, tissue differentiation-inducing non-protein coding RNA (TINCR) impairs the stability and expression of Krüppel-like factor 2 (KLF2) mRNA through SMD (Figure 1a). TINCR enables the stabilization of mRNAs by duplexing with mRNAs containing TINCR box motif [32].

Irrespective of the direct interaction, the indirect mode between lncRNAs and their targeted mRNAs is illustrated by metastasis-associated lung adenocarcinoma transcript 1 (MALAT1) (Figure 1b) and gastric carcinoma 
proliferation enhancing transcript 1 (GHET1) (Figure 1c). By binding with associated proteins, MALAT1 and GHET1 alter splicing or stability of mRNAs [33-35]. The function of serine/arginine splicing factors (SF2/ASF) relies on MALAT1 (Figure 1b). Formed by a bipartite triple helix, MALAT1 promotes malignancy [36]. The fragment nearly 3' end of MALAT1 may be in charge of the metastatic potential [37].

GHET1 potentiates the combination between insulin-like growth factor 2 mRNA binding protein 1

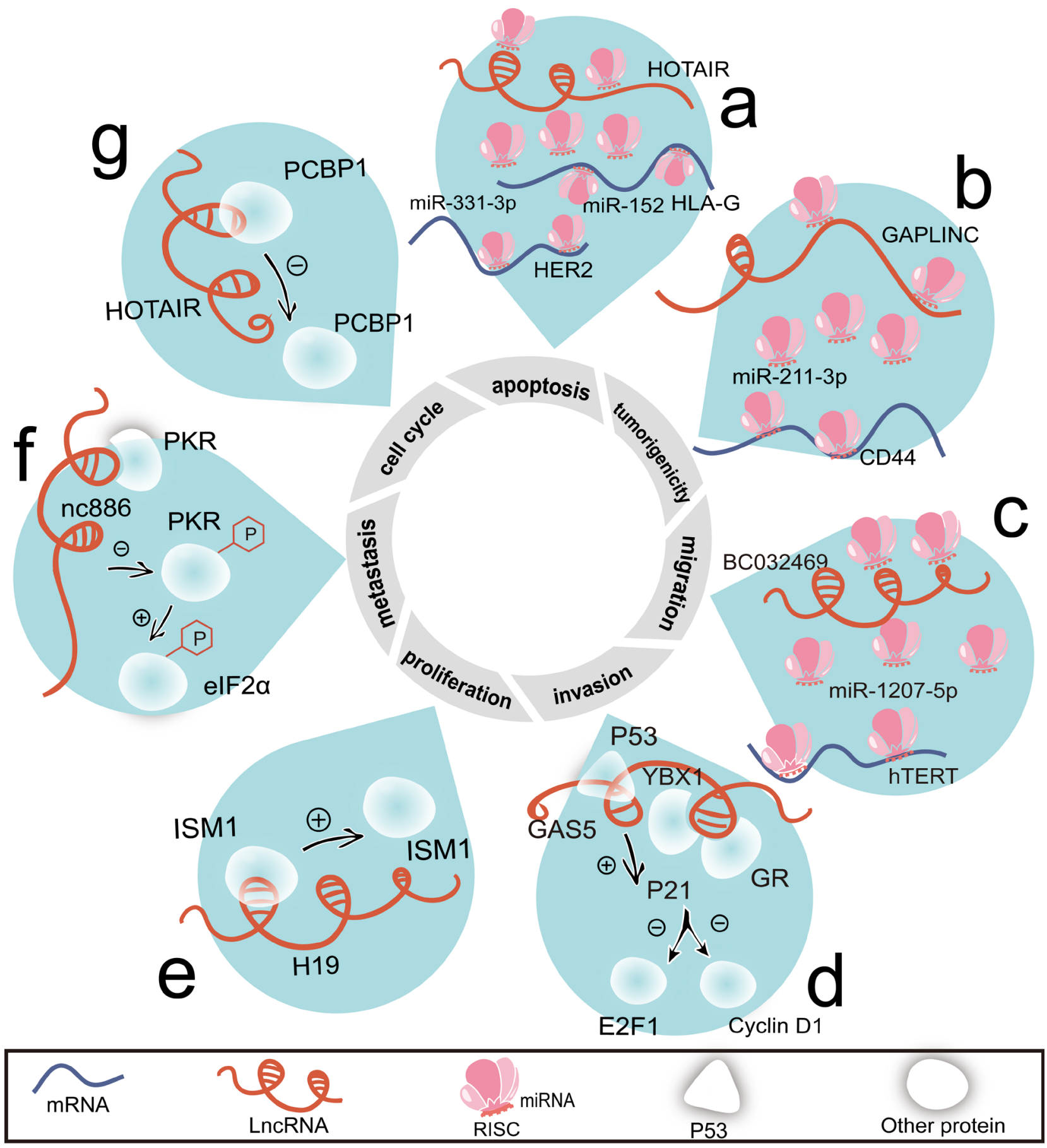

Figure 2: LncRNAs regulate cell proliferation, cell cycle, apoptosis, invasion, migration, metastasis, and tumorigenicity by interacting with proteins or acting as ceRNAs. a. There are two ceRNA networks associated with HOTAIR, HOTAIR/miR-3313p/HER2 mRNA and HOTAIR/miR-152/HLA-G mRNA. b. By sharing miR-211-3p, GAPLINC and CD44 become a pair of ceRNAs. c. Through sponging miR-1207-5p, BC032469 competes with hTERT mRNA. d. By binding with GR, YBX1 and P53, GAS5 elevates P21 level and represses the levels of E2F1 and cyclin D1. e. Combing with ISM1, H19 positively regulates its protein level. f. Nc886 represses the phosphorylation of PKR, thus blocking the phosphorylation of eIF2 $\alpha$. g. Binding with PCBP1, HOTAIR attenuates its protein level. Abbreviations: eIF $2 \alpha$, eukaryotic translation initiation factor 2 , subunit $1 \alpha$. 
(IGF2BP1) and c-Myc mRNA (Figure 1c). Albeit the short recognition element ( $\mathrm{CAUH}, \mathrm{H}=\mathrm{A}, \mathrm{U}$, or $\mathrm{C}$ ) of IGF2BP1 is extensively mapping to 8400 coding genes genomewide [38]. Remarkably, the motif CAUH is too short to format the secondary structure.

About a quarter of lncRNAs are consist of one or more Alu elements [30]. Inverted Alu repeats form long stable stem-loop structures and activate the post- transcription and translation [39, 40]. Interestingly, the long inverted repeats flanking the mouse Sry gene enable the formation of a circular RNA [41]. Apart from the secondary structure in repeat elements, it is likely that the special architectures of lncRNAs accelerate their functions. Therefore, high order structures of lncRNAs may conduce to the specific recognization with proteins and nucleic acids.

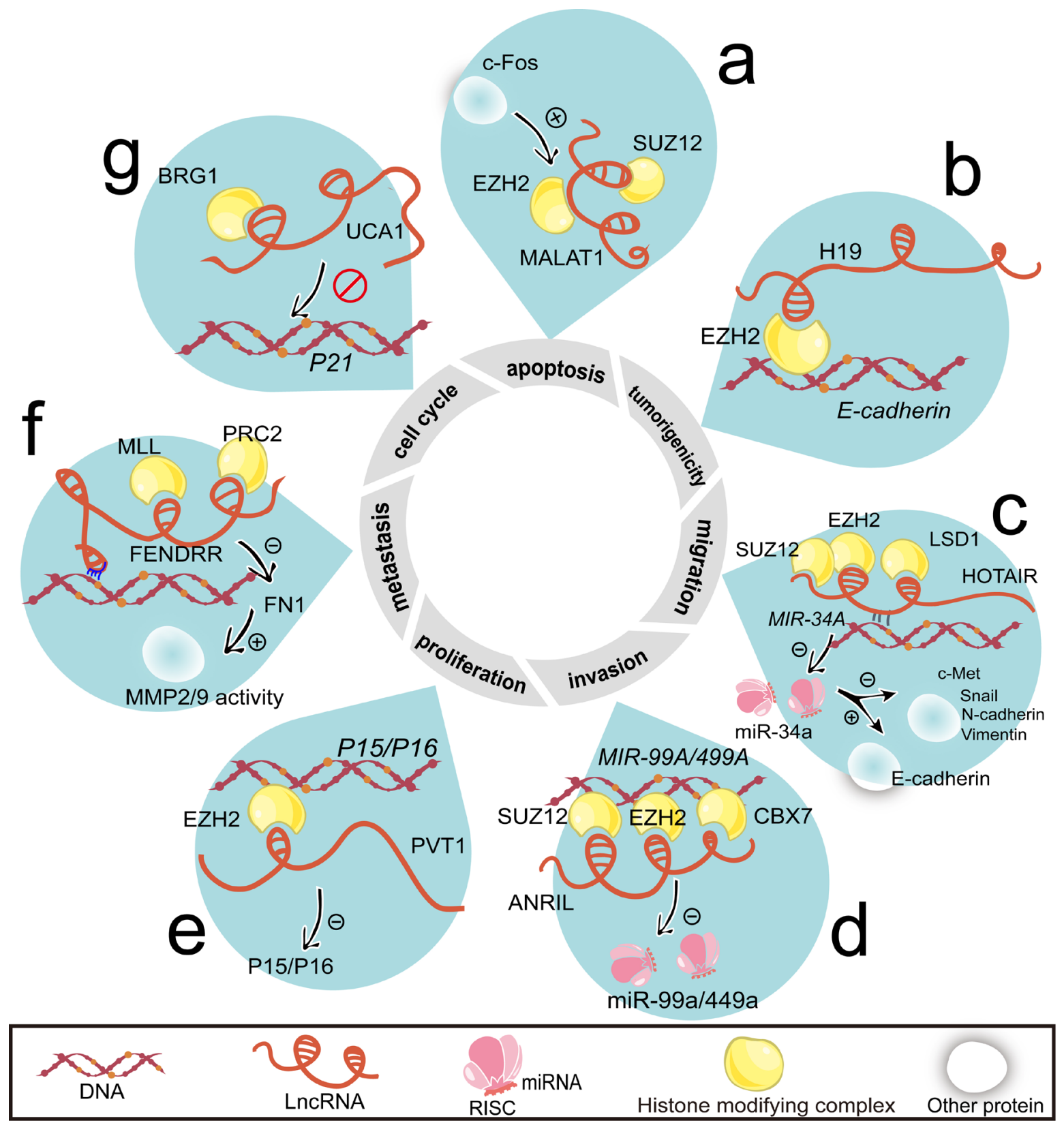

Figure 3: LncRNAs regulate cell proliferation, cell cycle, apoptosis, invasion, migration, metastasis, and tumorigenicity by histone modification. a. Activated by c-Fos, MALAT1 binds with EZH2 and SUZ12. b. H19 guides EZH2 to the E-cadherin promoter loci. c. Through the formation of dsDNA/RNA triplex, HOTAIR recruits SUZ12 and EZH2 to the MiR-34A loci and then silences the transcription of miR-34a. HOTAIR also forms complex with LSD1. HOTAIR attenuates c-Met, Snail, N-cadherin and Vimentin protein level while upregulates E-cadherin protein level. All of them are targets of miR-34a. d. ANRIL suppresses miR-49a/449a expression by the recruitment of EZH2 and SUZ12. ANRIL also combines with CBX7. e. The P15/P16 is silenced by the occupancy of EZH2, which is recruited by PVT1. f. Using its complementary fragment, FENDRR anchors with target DNA and guides MLL and PRC2 to the targeted genes. Additionally, FENDRR decreases MMP2/MMP9 activity by reducing FN1. g. Combining with BRG1, UCA1 impairs BRG1's ability to bind with $P 21$ promoter. Abbreviations: FN1, fironectin 1; MMP2/9, matrix metalloproteinase 2/9. 


\section{Interaction with miRNAs}

By assembly of RNA induced silencing complex (RISC), miRNAs lead mRNA degradation [42]. Studies showed that some lncRNAs are the precursors of miRNAs $[43,44]$. These mean that lncRNAs may affect mRNA degradation in a indirect way.

miR-675, processed from its precursor (imprinted maternally expressed transcript, H19), has the properties of promoting proliferation and epithelial-mesenchymal transition (EMT) (Figure 1d). H19 is capable of enhancing gastric carcinogenesis [45]. Plasma H19 levels in patients with gastric cancer are significantly higher than those in healthy controls [46].

Besides, lncRNAs' expressions may be repressed by miRNAs [47-49]. The situations in gastric cancer are

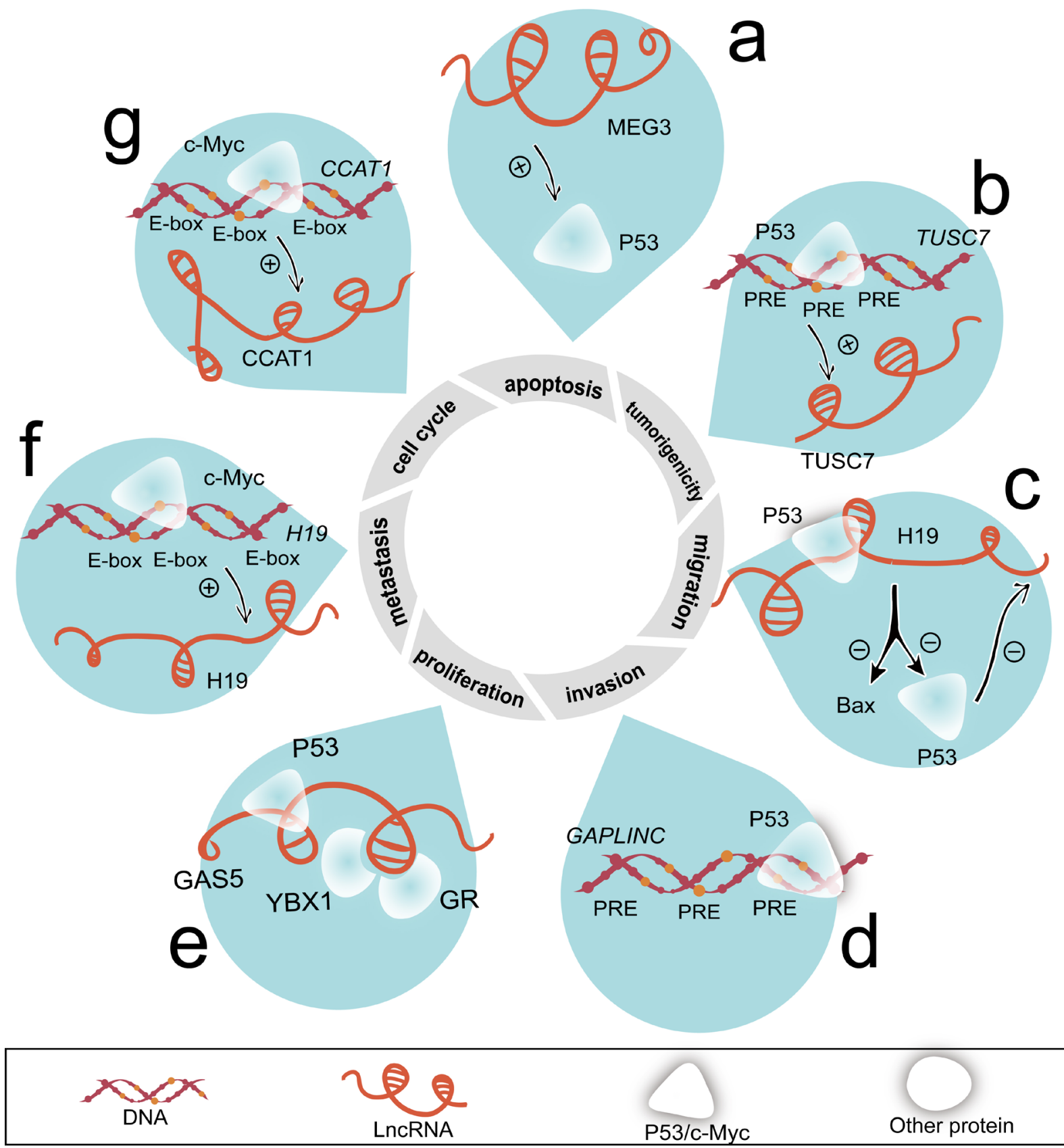

Figure 4: LncRNAs regulate cell proliferation, cell cycle, apoptosis, invasion, migration, metastasis, and tumorigenicity mediated by P53 and c-Myc. a. MEG3 accelerates P53 protein level. b. TUSC7 is transcriptionally activated by P53, which binds with PREs of its promoter. c. Combining with P53, H19 partially decreases P53 activity and BAX expression. d. P53 occupies the PREs on the promoter of GAPLINC. e. GAS5 combines with P53, YBX1 and GR. f. Using E-box, H19 is treated as a target of c-Myc. g. The abundance of CCAT1 is accelerated by c-Myc. c-Myc occupied the E-box on CCAT1 promoter region. Abbreviations: BAX, BCL2-associated X protein. 
sketched by tumor suppressor candidate 7 (TUSC7)/miR23b (Figure 1e), H19/miR-141 (Figure 1d), and maternally expressed 3 (MEG3)/miR-141 (Figure 1f).

Apart from miR-141, miR-148a shows an inhibitory effect on the expression of DNA methyltransferase 1 (DNMT-1) and thus induces the overexpression of MEG3 [50]. By recruiting polycomb repressive complex 2 (PRC2) to the functional sites [51], IncRNA-CDKN2B antisense RNA 1 (ANRIL) silences $M I R-99 A$ and $M I R-$ 449A (Figure 1g).

The examples about miRNAs' regulating lncRNAs via epigenetic modification, vice versa, can also be found in other parts of this article.

\section{LncRNAs acting as ceRNAs}

Emerging evidences suggest that lncRNAs may participate in competitive endogenous RNA (ceRNA) network [52], in which lncRNAs cross talk with other RNAs by sharing miRNAs.

Plasma HOTAIR levels in gastric cancer patients are higher than health controls [46]. Through the competitive 'sequestration' of miR-331-3p/miR-124, HOTAIR and erythroblastic leukemia viral oncogene homolog 2 (HER2) mRNA become a pair of ceRNAs in gastric cancer (Figure 2a). HER2 triggers malignant phenotype in gastric cancer upon drug resistant and EMT $[53,54]$. HOTAIR may be a novel target for HER2 positive patients who herald the high metastatic potential and poor survival [55]. Similarly, CD44 is a well-characterized glycoprotein involved in cancer metastasis [56]. Gastric adenocarcinoma predictive lincRNA (GAPLINC)/miR-211-3p/CD44 axis may also be applied to against metastasis (Figure 2b). Human leukocyte antigen-G (HLA-G) and human telomerase reverse transcriptase (hTERT) are both antigens expressed upon tumor cells $[57,58]$. The positive correlations of HOTAIR/HLA-G (Figure 2a) and lncRNA-BC032469/ hTERT (Figure 2c) provide potential immunotherapy targets on gastric cancer $[59,60]$.

Based on miRNA and lncRNA microarray data of gastric cancer, our group constructed a ceRNA network interlaced by gastric cancer-associated lncRNAs, miRNAs, and mRNAs [61]. For instance, fer-1-like family member 4, pseudogene (FER1L4), gastric cancer associated transcript 1 (GACAT1), and H19 may upregulate or downregulate the expression of PTEN, RB1, RUNX1, VEGFA, CDKN1A, E2F1, HIPK3, IL-10, or PAK7 by sharing miR-106a-5p [61, 62]. This deduction suggests that blocking the associations between lncRNAs and their partners (RNAs or proteins) may enable to cascade a significant effect.

\section{INTERACTION WITH PROTEINS}

\section{Interaction with histone-modifying complexes}

As many as 38\% lincRNAs cooperate with at least one of multiple histone-modifying complexes [63]. This suggests that one lncRNA may harbor several types of binding elements for chromatin modifiers. The specific locus is subject to the ensuing histone modification caused by the occupancy of histone-modifying complexes [64]. Apart from HOTAIR [65], PRC2 is found to communicate with other lncRNAs including ANRIL $[51,66]$, FENDRR [67], plasma-cytoma variant translocation 1 (PVT1) [68], MALAT1 (Figure 3a) and H19 (Figure 3b).

HOTAIR is the first demonstrated IncRNA coordinating gene silencing via assembly of PRC2 [69]. The structural domains of HOTAIR formed in its 5, region and 3 ' region are bound to enhancer of zeste 2 (EZH2, PRC2 subunit) and lysine specific demethylase 1 (LSD1), respectively [70]. HOTAIR preferentially occupies a GA-rich DNA motif to enable the formation of RNA:dsDNA triplex. This occurs independently of EZH2 [27]. Simultaneously, HOTAIR is required for the occupancy of suppressor of zeste 12 homolog (SUZ12, PRC2 subunit) on MIR-34A loci (Figure 3c). With the metastasis potential, H19 and HOTAIR epigenetically modify their targeted genes including E-cadherin (Figure 3b, c). Remarkably, the 1062 nt region at the 5' end of H19 is indispensable [71].

The manner of ANRIL to silence P15/INK4a and $P 16 / I N K 4 b$ in cis (Figure 3d) is different to that of PVT1 to $P 15 / I N K 4 a$ and P16/INK4b in trans (Figure 3e). ANRIL and PVT1 behave in the same pattern by EZH2 occupancy in the same site. The upregulated EZH2 enforces gastric cancer cell proliferation [68]. As an antisense lncRNA emanating from $I N K 4 b / A R F / I N K 4 a$, ANRIL is not only a cis-acting lncRNA, but also recruits PRC2 to the distant loci of MIR-99A/MIR-449A in gastric cancer (Figure 3d). Furthermore, by downregulating serine/threonine kinase mTOR and cyclin-dependent kinase 6 (CDK6)/ E2F transcription factor 1 (E2F1) pathways, miR-99a/miR449a indirectly induce the expression of ANRIL [55]. This is a positive feedback loop. Interestingly, CDK6 represents as a bona fide INK4b/ARF/INK4a downstream effector. Meanwhile, ANRIL tethers PRC1 subunit chromobox homolog 7 (CBX7) to target genes (Figure 3d).

LncRNAs also recruit activating chromatin modifiers such as lysine (K)-specific methyltransferase 2A (MLL) [26]. FENDRR acts as a propeller for metastasis in gastric cancer [22]. The FENDRR/PRC2 complex may antagonize FENDRR/MLL (Figure 3f). However, rare change caused by FENDRR in its host gene FOXF1 is observed in gastric cancer [22]. Regardless of promotion effect of lncRNAs on the binding of chromatin-remolding 
complex, lncRNA-urothelial cancer associated 1 (UCA1) impairs SMARCA4/BRG1 binding to cyclin-dependent kinase inhibitor 1A (P21) promoter (Figure 3g). The full name of SMARCA4 is SWI/SNF related, matrix associated, actin-dependent regulator of chromatin, subfamily A, member 4 [78]. It can be noted that BRG1 mediates eviction of the PRC1 and PRC2 at INK4b/ARF/ INK4 $a$ locus [72]. PRC2 is recruited by ANRIL and PVT1 to the same site.

\section{Interaction with P53 and c-Myc}

Among the transcription factors (TFs) activating carcinogenesis, P53 and c-Myc represent potent inducers. The proliferative subtype is a well-defined subtype of gastric cancer characterized by $p 53$ mutations, DNA hypermethylation, as well as activated E2F, Myc and Ras oncogenic pathways [73]. H19 is concordantly stimulated by tumor suppressor P53 [74] and onco-protein c-Myc [75].

Recent study identified several lincRNA loci enriching consensus P53 responsive elements (PREs) [76]. Meanwhile, ten differentially expressed lncRNAs potentially manipulate the P53 signaling pathway in gastric cancer [77]. Several lncRNAs including MEG3 (Figure 4a), TUSC7 (Figure 4b), and H19 (Figure 4c) execute wild type P53 instructions and also serve as regulators of wild type P53 [47, 74, 78, 79]. Moreover, the folding of full length MEG3 is crucial for inducing significant increase of P53 levels [80]. GAPLINC promoter contains mutant P53-binding motif (Figure 4d). Growth arrest-specific 5 (GAS5) bounds to P53/ Y box binding protein 1 (YBX1) complex and upregulates P21 expression [81] (Figure 4e).

Myc protein contains a basic DNA binding domain that binds to E-box DNA recognition fragment (CACGTG) [82]. $\mathrm{CpG}$ islands and pre-acetylated state of chromatin enable high affinity of sites bound to c-Myc [83]. c-Myc is overexpressed in $43 \%$ gastric cancer patients [84]. Microarray results indicated that 1244 lncRNAs are directly activated by c-Myc [85]. Remarkably, two lncRNAs, H19 (Figure 4f) and colon cancer associated transcript 1 (CCAT1) (Figure 4g) are transcriptionally activated by c-Myc in gastric cancer $[75,86]$. In addition, the active regulatory region of the CCAT1 site occurs physically interaction with $c-M y c$ enhancer region [87].

\section{Interaction with other proteins}

With the exception of the direct interaction with proteins, how do lncRNAs regulate the levels of proteins is arresting. GAS5 positively influences YBX1 protein stability without increasing its transcription [81]. The putative stem-loop structure formed by exon 12 of GAS5 is responsible for its interplay with YBX1 (Figure 2d). YBX1 possesses the capacity of complexing with
IGF2BP1 [88], which combines with GHET1 and prevents mRNA degradation [33]. The exon 12 is a GAS5's predominant structural domain for mimicking binding domain of glucocorticoid receptor (GR) [89]. GAS5, GR, YBX1, and P53 may collaborate as complex to achieve cell cycle regulation [90] (Figure 2d).

H19 is found bound with Isthmin 1 (ISM1) [45] and positively regulates its expression (Figure 2e). ISM1 is a factor promoting endothelial cell survival and cell death synchronously [91]. This may explain why H19's role converts between multiple cancers. H19's high expression level enforces the oncogenic progress of gastric cancer cells; while in hepatocellular carcinoma (HCC), it is recognized as tumor suppressor [92]. Additionally, H19derived miR-675 may succeed in causing the alterations of ISM1 [45].

There are also inhibitory effects of lncRNAs on the binding proteins, such as nc886 on double stranded RNAdependent protein kinase (PKR) (Figure 2f) and HOTAIR on poly $(\mathrm{C})$ binding protein 1 (PCBP1) (Figure $2 \mathrm{~g}$ ). PKR recognizes single strand nucleotide sequence in the central region of nc886 [93], which deviates from canonical PKR ligands with abundant hairpin structures [94]. In this way, nc886 displays its anti-apoptotic ability in a cell type dependent manner [95] (Figure 2f). PCBP1 inactivates the AKT pathway to against metastatic progression [96]. This finding per se matches the potential of HOTAIR in metastasis in gastric cancer.

\section{CONCLUSIONS}

LncRNAs are characterized by the complexity of their mechanisms. We summarized lncRNAs' interaction with DNA, RNA, and proteins in gastric cancer occurrences.

It is tempting to speculate that a multitude of lncRNAs may interrupt definitive steps in numerous tumor suppressive and oncogenic pathways. The uncovering of the underlying mechanisms of lncRNAs may benefit our understanding of gastric cancer's pathogenesis.

\section{ACKNOWLEDGMENTS}

This work was supported by the Natural Science Foundation of Zhejiang Province (No. LY14C060003), the Applied Research Project on Nonprofit Technology of Zhejiang Province (No. 2014C33222), the National Natural Science Foundation of China (No. 81171660), Graduate Innovation Research Foundation of Ningbo University (No. G15074) and the K. C. Wong Magna Fund in Ningbo University.

\section{CONFLICTS OF INTEREST}

The authors declare no conflict of interests. 


\section{REFERENCES}

1. Rinn JL, Chang HY. Genome regulation by long noncoding RNAs. Annu Rev Biochem. 2012; 81: 145-166.

2. Di Gesualdo F, Capaccioli S, Lulli M. A pathophysiological view of the long non-coding RNA world. Oncotarget. 2014; 5: 10976-10996. doi: 10.18632/oncotarget.2770.

3. Qi P, Du X. The long non-coding RNAs, a new cancer diagnostic and therapeutic gold mine. Mod Pathol. 2013; 26: $155-165$.

4. Torre LA, Bray F, Siegel RL, Ferlay J, Lortet-Tieulent J, Jemal A. Global cancer statistics, 2012. CA Cancer J Clin. 2015; 65: 87-108.

5. Song H, Sun W, Ye G, Ding X, Liu Z, Zhang S, Xia T, Xiao $\mathrm{B}, \mathrm{Xi} \mathrm{Y}$, Guo J. Long non-coding RNA expression profile in human gastric cancer and its clinical significances. J Transl Med. 2013; 11: 225.

6. Li H, Yu B, Li J, Su L, Yan M, Zhang J, Li C, Zhu Z, Liu B. Characterization of differentially expressed genes involved in pathways associated with gastric cancer. PLoS One. 2015; 10: e0125013.

7. Mei D, Song H, Wang K, Lou Y, Sun W, Liu Z, Ding $X$, Guo J. Up-regulation of SUMO1 pseudogene 3 (SUMO1P3) in gastric cancer and its clinical association. Med Oncol. 2013; 30: 709.

8. Zhu S, Mao J, Shao Y, Chen F, Zhu X, Xu D, Zhang X, Guo J. Reduced expression of the long non-coding RNA AI364715 in gastric cancer and its clinical significance. Tumour Biol. 2015; 36: 8041-8045.

9. Li Q, Shao Y, Zhang X, Zheng T, Miao M, Qin L, Wang B, Ye G, Xiao B, Guo J. Plasma long noncoding RNA protected by exosomes as a potential stable biomarker for gastric cancer. Tumour Biol. 2014; 36: 2007-2012.

10. Shao Y, Chen H, Jiang X, Chen S, Li P, Ye M, Li Q, Sun W, Guo J. Low expression of lncRNA-HMlincRNA717 in human gastric cancer and its clinical significances. Tumour Biol. 2014; 35: 9591-9595.

11. Xu C, Shao Y, Xia T, Yang Y, Dai J, Luo L, Zhang X, Sun W, Song H, Xiao B, Guo J. LncRNA-AC130710 targeting by miR-129-5p is upregulated in gastric cancer and associates with poor prognosis. Tumour Biol. 2014; 35: 9701-9706.

12. Lin X, Yang M, Xia T, Guo J. Increased expression of long noncoding RNA ABHD11-AS1 in gastric cancer and its clinical significance. Med Oncol. 2014; 31: 42.

13. Pang Q, Ge J, Shao Y, Sun W, Song H, Xia T, Xiao B, Guo J. Increased expression of long intergenic non-coding RNA LINC00152 in gastric cancer and its clinical significance. Tumour Biol. 2014; 35: 5441-5447.

14. Shao Y, Ye M, Jiang X, Sun W, Ding X, Liu Z, Ye G, Zhang X, Xiao B, Guo J. Gastric juice long noncoding RNA used as a tumor marker for screening gastric cancer. Cancer. 2014; 120: 3320-3328.

15. Wan X, Ding X, Chen S, Song H, Jiang H, Fang Y, Li P,
Guo J. The functional sites of miRNAs and lncRNAs in gastric carcinogenesis. Tumour Biol. 2015; 36: 521-532.

16. Sun W, Wu Y, Yu X, Liu Y, Song H, Xia T, Xiao B, Guo J. Decreased expression of long noncoding RNA AC096655.1-002 in gastric cancer and its clinical significance. Tumour Biol. 2013; 34: 2697-2701.

17. Liu Z, Shao Y, Tan L, Shi H, Chen S, Guo J. Clinical significance of the low expression of FER1L4 in gastric cancer patients. Tumour Biol. 2014; 35: 9613-9617.

18. Hu Y, Wang J, Qian J, Kong X, Tang J, Wang Y, Chen H, Hong J, Zou W, Chen Y, Xu J, Fang JY. Long noncoding RNA GAPLINC regulates CD44-dependent cell invasiveness and associates with poor prognosis of gastric cancer. Cancer Res. 2014; 74: 6890-6902.

19. Okugawa Y, Toiyama Y, Hur K, Toden S, Saigusa S, Tanaka K, Inoue Y, Mohri Y, Kusunoki M, Boland CR, Goel A. Metastasis-associated long non-coding RNA drives gastric cancer development and promotes peritoneal metastasis. Carcinogenesis. 2014; 35: 2731-2739.

20. Endo H, Shiroki T, Nakagawa T, Yokoyama M, Tamai K, Yamanami H, Fujiya T, Sato I, Yamaguchi K, Tanaka N, Iijima K, Shimosegawa T, Sugamura K, et al. Enhanced expression of long non-coding RNA HOTAIR is associated with the development of gastric cancer. PLoS One. 2013; 8: e77070.

21. Zhang ZZ, Shen ZY, Shen YY, Xu J, Zhao EH, Wang M, Wang CJ, Cao H. HOTAIR long noncoding RNA promotes gastric cancer metastasis through suppression of Poly $\mathrm{r}(\mathrm{C})$ Binding Protein (PCBP) 1. Mol Cancer Ther. 2015; 14: 1162-1170.

22. Xu TP, Huang MD, Xia R, Liu XX, Sun M, Yin L, Chen WM, Han L, Zhang EB, Kong R, De W, Shu YQ. Decreased expression of the long non-coding RNA FENDRR is associated with poor prognosis in gastric cancer and FENDRR regulates gastric cancer cell metastasis by affecting fibronectin1 expression. J Hematol Oncol. 2014; 7: 63.

23. Chen F, Tian Y, Pang EJ, Wang Y, Li L. MALAT2activated long noncoding RNA indicates a biomarker of poor prognosis in gastric cancer. Cancer Gene Ther. 2015; doi: 10.1038/cgt.2015.6.

24. Yan Y, Shen Z, Gao Z, Cao J, Yang Y, Wang B, Shen C, Mao S, Jiang K, Ye Y, Wang S. Long noncoding ribonucleic acid specific for distant metastasis of gastric cancer is associated with TRIM16 expression and facilitates tumor cell invasion in vitro. J Gastroenterol Hepatol. 2015; 30: 1367-1375.

25. Margueron R, Reinberg D. The Polycomb complex PRC2 and its mark in life. Nature. 2011; 469: 343-349.

26. Grote P, Herrmann BG. The long non-coding RNA FENDRR links epigenetic control mechanisms to gene regulatory networks in mammalian embryogenesis. RNA Biol. 2013; 10: 1579-1585.

27. Chu C, Qu K, Zhong FL, Artandi SE, Chang HY. Genomic 
maps of long noncoding RNA occupancy reveal principles of RNA-chromatin interactions. Mol Cell. 2011; 44: 667678.

28. Martianov I, Ramadass A, Serra Barros A, Chow N, Akoulitchev A. Repression of the human dihydrofolate reductase gene by a non-coding interfering transcript. Nature. 2007; 445: 666-670.

29. Simon MD, Wang CI, Kharchenko PV, West JA, Chapman BA, Alekseyenko AA, Borowsky ML, Kuroda MI, Kingston RE. The genomic binding sites of a noncoding RNA. Proc Natl Acad Sci USA. 2011; 108: 20497-20502.

30. Gong C, Maquat LE. LncRNAs transactivate STAU1mediated mRNA decay by duplexing with 3' UTRs via Alu elements. Nature. 2011; 470: 284-288.

31. Xu TP, Liu XX, Xia R, Yin L, Kong R, Chen WM, Huang $\mathrm{MD}$, Shu YQ. SP1-induced upregulation of the long noncoding RNA TINCR regulates cell proliferation and apoptosis by affecting KLF2 mRNA stability in gastric cancer. Oncogene. 2015; 34: 5648-5661.

32. Kretz M, Siprashvili Z, Chu C, Webster DE, Zehnder A, Qu K, Lee CS, Flockhart RJ, Groff AF, Chow J, Johnston D, Kim GE, Spitale RC, et al. Control of somatic tissue differentiation by the long non-coding RNA TINCR. Nature. 2013; 493: 231-235.

33. Yang F, Xue X, Zheng L, Bi J, Zhou Y, Zhi K, Gu Y, Fang G. Long non-coding RNA GHET1 promotes gastric carcinoma cell proliferation by increasing c-Myc mRNA stability. FEBS J. 2014; 281: 802-813.

34. Wang J, Su L, Chen X, Li P, Cai Q, Yu B, Liu B, Wu W, Zhu Z. MALAT1 promotes cell proliferation in gastric cancer by recruiting SF2/ASF. Biomed Pharmacother. 2014; 68: 557-564.

35. Tripathi V, Ellis JD, Shen Z, Song DY, Pan Q, Watt AT, Freier SM, Bennett CF, Sharma A, Bubulya PA, Blencowe BJ, Prasanth SG, Prasanth KV. The nuclear-retained noncoding RNA MALAT1 regulates alternative splicing by modulating SR splicing factor phosphorylation. Mol Cell. 2010; 39: 925-938.

36. Brown JA, Bulkley D, Wang J, Valenstein ML, Yario TA, Steitz TA, Steitz JA. Structural insights into the stabilization of MALAT1 noncoding RNA by a bipartite triple helix. Nat Struct Mol Biol. 2014; 21: 633-640.

37. Xu C, Yang M, Tian J, Wang X, Li Z. MALAT-1: A long non-coding RNA and its important 3' end functional motif in colorectal cancer metastasis. Int J Oncol. 2011; 39: 169175.

38. Hafner M, Landthaler M, Burger L, Khorshid M, Hausser J, Berninger P, Rothballer A, Jr MA, Jungkamp AC, Munschauer M, Ulrich A, Wardle GS, Dewell S, et al. Transcriptome-wide identification of RNA-binding protein and microRNA target sites by PAR-CLIP. Cell. 2010; 141: 129-141.

39. Daniel C, Silberberg G, Behm M, Ohman M. Alu elements shape the primate transcriptome by cis-regulation of RNA editing. Genome Biol. 2014; 15: R28.

40. Hasler J, Samuelsson T, Strub K. Useful 'junk': Alu RNAs in the human transcriptome. Cell Mol Life Sci. 2007; 64: 1793-1800.

41. Dubin RA, Kazmi MA, Ostrer H. Inverted repeats are necessary for circularization of the mouse testis Sry transcript. Gene. 1995; 167: 245-248.

42. Tijsterman M, Plasterk RH. Dicers at RISC; the mechanism of RNAi. Cell. 2004; 117: 1-3.

43. Matouk IJ, Raveh E, Abu-lail R, Mezan S, Gilon M, Gershtain E, Birman T, Gallula J, Schneider T, Barkali M, Richler C, Fellig Y, Sorin V, et al. Oncofetal H19 RNA promotes tumor metastasis. Biochim Biophys Acta. 2014; 1843: 1414-1426.

44. Wilusz JE, Freier SM, Spector DL. 3' end processing of a long nuclear-retained noncoding RNA yields a tRNA-like cytoplasmic RNA. Cell. 2008; 135: 919-932.

45. Li H, Yu B, Li J, Su L, Yan M, Zhu Z, Liu B. Overexpression of lncRNA H19 enhances carcinogenesis and metastasis of gastric cancer. Oncotarget. 2014; 5: 23182329. doi: 10.18632/oncotarget.1913.

46. Zhou X, Yin C, Dang Y, Ye F, Zhang G. Identification of the long non-coding RNA H19 in plasma as a novel biomarker for diagnosis of gastric cancer. Sci Rep. 2015; 5: 11516.

47. Qi P, Xu MD, Shen XH, Ni SJ, Huang D, Tan C, Weng WW, Sheng WQ, Zhou XY, Du X. Reciprocal repression between TUSC7 and miR-23b in gastric cancer. Int J Cancer. 2015; 137: 1269-1278.

48. Zhou X, Ye F, Yin C, Zhuang Y, Yue G, Zhang G. The interaction between miR-141 and lncRNA-H19 in regulating cell proliferation and migration in gastric cancer. Cell Physiol Biochem. 2015; 36: 1440-1452.

49. Zhou X, Ji G, Ke X, Gu H, Jin W, Zhang G. MiR-141 inhibits gastric cancer proliferation by interacting with long noncoding RNA MEG3 and down-regulating E2F3 expression. Dig Dis Sci. 2015; 60: 3271-3282.

50. Yan J, Guo X, Xia J, Shan T, Gu C, Liang Z, Zhao W, Jin S. MiR-148a regulates MEG3 in gastric cancer by targeting DNA methyltransferase 1. Med Oncol. 2014; 31: 879.

51. Zhang EB, Kong R, Yin DD, You LH, Sun M, Han L, Xu TP, Xia R, Yang JS, De W, Chen J. Long noncoding RNA ANRIL indicates a poor prognosis of gastric cancer and promotes tumor growth by epigenetically silencing of miR-99a/miR-449a. Oncotarget. 2014; 5: 2276-2292. doi: 10.18632/oncotarget.1902.

52. Liang WC, Fu WM, Wong CW, Wang Y, Wang WM, Hu GX, Zhang L, Xiao LJ, Wan DC, Zhang JF, Waye MM. The lncRNA H19 promotes epithelial to mesenchymal transition by functioning as miRNA sponges in colorectal cancer. Oncotarget. 2015; 6: 22513-22525. doi: 10.18632/ oncotarget.4154.

53. Matsui Y, Inomata M, Tojigamori M, Sonoda K, Shiraishi N, Kitano S. Suppression of tumor growth in human 
gastric cancer with HER2 overexpression by an anti-HER2 antibody in a murine model. Int J Oncol. 2005; 27: 681-685.

54. Kim HP, Han SW, Song SH, Jeong EG, Lee MY, Hwang D, Im SA, Bang YJ, Kim TY. Testican-1-mediated epithelialmesenchymal transition signaling confers acquired resistance to lapatinib in HER2-positive gastric cancer. Oncogene. 2014; 33: 3334-3341.

55. Liu XH, Sun M, Nie FQ, Ge YB, Zhang EB, Yin DD, Kong R, Xia R, Lu KH, Li JH, De W, Wang KM, Wang ZX. LncRNA HOTAIR functions as a competing endogenous RNA to regulate HER2 expression by sponging miR-331$3 p$ in gastric cancer. Mol Cancer. 2014; 13: 92.

56. Williams K, Motiani K, Giridhar PV, Kasper S. CD44 integrates signaling in normal stem cell, cancer stem cell and (pre)metastatic niches. Exp Biol Med. 2013; 238: 324338.

57. Pistoia V, Morandi F, Wang X, Ferrone S. Soluble HLA-G: Are they clinically relevant? Semin Cancer Biol. 2007; 17: 469-479.

58. Lu MH, Liao ZL, Zhao XY, Fan YH, Lin XL, Fang DC, Guo H, Yang SM. HTERT-based therapy: A universal anticancer approach. Oncol Rep. 2012; 28: 1945-1952.

59. Song B, Guan Z, Liu F, Sun D, Wang K, Qu H. Long non-coding RNA HOTAIR promotes HLA-G expression via inhibiting miR-152 in gastric cancer cells. Biochem Biophys Res Commun. 2015; 464: 807-813.

60. Chen L, Lu MH, Zhang D, Hao NB, Fan YH, Wu YY, Wang SM, Xie R, Fang DC, Zhang H, Hu CJ, Yang SM. MiR-1207-5p and miR-1266 suppress gastric cancer growth and invasion by targeting telomerase reverse transcriptase. Cell Death Dis. 2014; 5: e1034.

61. Xia T, Liao Q, Jiang X, Shao Y, Xiao B, Xi Y, Guo J. Long noncoding RNA associated-competing endogenous RNAs in gastric cancer. Sci Rep. 2014; 4: 6088.

62. Xia T, Chen S, Jiang Z, Shao Y, Jiang X, Li P, Xiao B, Guo J. Long noncoding RNA FER1L4 suppresses cancer cell growth by acting as a competing endogenous RNA and regulating PTEN expression. Sci Rep. 2015; 5: 13445.

63. Khalil AM, Guttman M, Huarte M, Garber M, Raj A, Rivea Morales D, Thomas K, Presser A, Bernstein BE, van Oudenaarden A, Regev A, Lander ES, Rinn JL. Many human large intergenic noncoding RNAs associate with chromatin-modifying complexes and affect gene expression. Proc Natl Acad Sci USA. 2009; 106: $11667-$ 11672.

64. Kang C, Song JJ, Lee J, Kim MY. Epigenetics: An emerging player in gastric cancer. World J Gastroenterol. 2014; 20: 6433-6447.

65. Liu YW, Sun M, Xia R, Zhang EB, Liu XH, Zhang ZH, Xu TP, De W, Liu BR, Wang ZX. LincHOTAIR epigenetically silences miR34a by binding to PRC2 to promote the epithelial-to-mesenchymal transition in human gastric cancer. Cell Death Dis. 2015; 6: e1802.

66. Yap KL, Li S, Munoz-Cabello AM, Raguz S, Zeng L,
Mujtaba S, Gil J, Walsh MJ, Zhou MM. Molecular interplay of the noncoding RNA ANRIL and methylated histone H3 lysine 27 by polycomb CBX7 in transcriptional silencing of INK4a. Mol Cell. 2010; 38: 662-674.

67. Grote P, Wittler L, Hendrix D, Koch F, Wahrisch S, Beisaw A, Macura K, Blass G, Kellis M, Werber M, Herrmann BG. The tissue-specific lncRNA FENDRR is an essential regulator of heart and body wall development in the mouse. Dev Cell. 2013; 24: 206-214.

68. Kong R, Zhang EB, Yin DD, You LH, Xu TP, Chen WM, Xia R, Wan L, Sun M, Wang ZX, De W, Zhang ZH. Long noncoding RNA PVT1 indicates a poor prognosis of gastric cancer and promotes cell proliferation through epigenetically regulating p15 and p16. Mol Cancer. 2015; 14: 82 .

69. Rinn JL, Kertesz M, Wang JK, Squazzo SL, Xu X, Brugmann SA, Goodnough LH, Helms JA, Farnham PJ, Segal E, Chang HY. Functional demarcation of active and silent chromatin domains in human HOX loci by noncoding RNAs. Cell. 2007; 129: 1311-1323.

70. Tsai MC, Manor O, Wan Y, Mosammaparast N, Wang JK, Lan F, Shi Y, Segal E, Chang HY. Long noncoding RNA as modular scaffold of histone modification complexes. Science. 2010; 329: 689-693.

71. Luo M, Li Z, Wang W, Zeng Y, Liu Z, Qiu J. Long noncoding RNA H19 increases bladder cancer metastasis by associating with EZH2 and inhibiting E-cadherin expression. Cancer Lett. 2013; 333: 213-221.

72. Kia SK, Gorski MM, Giannakopoulos S, Verrijzer CP. $\mathrm{SWI} / \mathrm{SNF}$ mediates polycomb eviction and epigenetic reprogramming of the INK4b-ARF-INK4a locus. Mol Cell Biol. 2008; 28: 3457-3464.

73. Lei Z, Tan IB, Das K, Deng N, Zouridis H, Pattison S, Chua C, Feng Z, Guan YK, Ooi CH, Ivanova T, Zhang S, Lee $\mathrm{M}$, et al. Identification of molecular subtypes of gastric cancer with different responses to PI3-kinase inhibitors and 5-fluorouracil. Gastroenterology. 2013; 145: 554-565.

74. Yang F, Bi J, Xue X, Zheng L, Zhi K, Hua J, Fang G. Up-regulated long non-coding RNA H19 contributes to proliferation of gastric cancer cells. FEBS J. 2012; 279: 3159-3165.

75. Zhang EB, Han L, Yin DD, Kong R, De W, Chen J. c-Mycinduced, long, noncoding $\mathrm{H} 19$ affects cell proliferation and predicts a poor prognosis in patients with gastric cancer. Med Oncol. 2014; 31: 914.

76. Huarte M, Guttman M, Feldser D, Garber M, Koziol MJ, Kenzelmann-Broz D, Khalil AM, Zuk O, Amit I, Rabani M, Attardi LD, Regev A, Lander ES, et al. A large intergenic noncoding RNA induced by p53 mediates global gene repression in the p53 response. Cell. 2010; 142: 409-419.

77. Lin XC, Zhu Y, Chen WB, Lin LW, Chen DH, Huang JR, Pan K, Lin Y, Wu BT, Dai Y, Tu ZG. Integrated analysis of long non-coding RNAs and mRNA expression profiles reveals the potential role of lncRNAs in gastric cancer 
pathogenesis. Int J Oncol. 2014; 45: 619-628.

78. Sun M, Xia R, Jin F, Xu T, Liu Z, De W, Liu X. Downregulated long noncoding RNA MEG3 is associated with poor prognosis and promotes cell proliferation in gastric cancer. Tumour Biol. 2014; 35: 1065-1073.

79. Dugimont T, Montpellier C, Adriaenssens E, Lottin S, Dumont L, Iotsova V, Lagrou C, Stehelin D, Coll J, Curgy JJ. The H19 TATA-less promoter is efficiently repressed by wild-type tumor suppressor gene product P53. Oncogene. 1998; 16: 2395-2401.

80. Zhou Y, Zhong Y, Wang Y, Zhang X, Batista DL, Gejman R, Ansell PJ, Zhao J, Weng C, Klibanski A. Activation of p53 by MEG3 non-coding RNA. J Biol Chem. 2007; 282: 24731-24742.

81. Liu Y, Zhao J, Zhang W, Gan J, Hu C, Huang G, Zhang Y. LncRNA GAS5 enhances G1 cell cycle arrest via binding to $\mathrm{YBX} 1$ to regulate $\mathrm{p} 21$ expression in stomach cancer. Sci Rep. 2015; 5: 10159 .

82. Blackwood EM, Eisenman RN. Max: A helix-loop-helix zipper protein that forms a sequence-specific DNA-binding complex with Myc. Science. 1991; 251: 1211-1217.

83. Fernandez PC, Frank SR, Wang L, Schroeder M, Liu S, Greene J, Cocito A, Amati B. Genomic targets of the human c-Myc protein. Genes Dev. 2003; 17: 1115- 1129.

84. Milne AN, Carvalho R, Morsink FM, Musler AR, de Leng WW, Ristimaki A, Offerhaus GJ. Early-onset gastric cancers have a different molecular expression profile than conventional gastric cancers. Mod Pathol. 2006; 19: 564572.

85. Winkle M, van den Berg A, Tayari M, Sietzema J, Terpstra M, Kortman G, de Jong D, Visser L, Diepstra A, Kok K, Kluiver J. Long noncoding RNAs as a novel component of the Myc transcriptional network. FASEB J. 2015; 29: 23382346.

86. Yang F, Xue X, Bi J, Zheng L, Zhi K, Gu Y, Fang G. Long noncoding RNA CCAT1, which could be activated by c-Myc, promotes the progression of gastric carcinoma. J Cancer Res Clin Oncol. 2013; 139: 437-445.

87. Kim T, Cui R, Jeon YJ, Lee JH, Lee JH, Sim H, Park JK, Fadda P, Tili E, Nakanishi H, Huh MI, Kim SH, Cho JH, et al. Long-range interaction and correlation between MYC enhancer and oncogenic long noncoding RNA CARLo-5. Proc Natl Acad Sci USA. 2014; 111: 4173-4178.

88. Weidensdorfer D, Stohr N, Baude A, Lederer M, Kohn M, Schierhorn A, Buchmeier S, Wahle E, Huttelmaier S. Control of c-Myc mRNA stability by IGF2BP1-associated cytoplasmic RNPs. RNA. 2009; 15: 104-115.

89. Kino $\mathrm{T}$, Hurt DE, Ichijo $\mathrm{T}$, Nader $\mathrm{N}$, Chrousos GP. Noncoding RNA GAS5 is a growth arrest- and starvationassociated repressor of the glucocorticoid receptor. Sci Signal. 2010; 3: ra8.

90. Sun M, Jin FY, Xia R, Kong R, Li JH, Xu TP, Liu YW, Zhang EB, Liu XH, De W. Decreased expression of long noncoding RNA GAS5 indicates a poor prognosis and promotes cell proliferation in gastric cancer. BMC Cancer. 2014; 14: 319.

91. Zhang Y, Chen M, Venugopal S, Zhou Y, Xiang W, Li YH, Lin Q, Kini RM, Chong YS, Ge R. Isthmin exerts prosurvival and death-promoting effect on endothelial cells through alphavbeta5 integrin depending on its physical state. Cell Death Dis. 2011; 2: e153.

92. Zhang L, Yang F, Yuan JH, Yuan SX, Zhou WP, Huo XS, $\mathrm{Xu}$ D, Bi HS, Wang F, Sun SH. Epigenetic activation of the miR-200 family contributes to H19-mediated metastasis suppression in hepatocellular carcinoma. Carcinogenesis. 2013; 34: 577- 586.

93. Jeon $\mathrm{SH}$, Lee $\mathrm{K}$, Lee KS, Kunkeaw N, Johnson BH, Holthauzen LM, Gong B, Leelayuwat C, Lee YS. Characterization of the direct physical interaction of nc886, a cellular non-coding RNA, and PKR. FEBS Lett. 2012; 586: 3477-3484.

94. Heinicke LA, Wong CJ, Lary J, Nallagatla SR, DiegelmanParente A, Zheng X, Cole JL, Bevilacqua PC. RNA dimerization promotes PKR dimerization and activation. $\mathrm{J}$ Mol Biol. 2009; 390: 319-338.

95. Lee KS, Park JL, Lee K, Richardson LE, Johnson BH, Lee HS, Lee JS, Kim SB, Kwon OH, Song KS, Kim YS, Ashktorab H, Smoot DT, et al. Nc886, a non-coding RNA of anti-proliferative role, is suppressed by $\mathrm{CpG}$ DNA methylation in human gastric cancer. Oncotarget. 2014; 5: 3944-3955. doi: 10.18632/oncotarget.2047.

96. Wang H, Vardy LA, Tan CP, Loo JM, Guo K, Li J, Lim SG, Zhou J, Chng WJ, Ng SB, Li HX, Zeng Q. PCBP1 suppresses the translation of metastasis-associated PRL-3 phosphatase. Cancer Cell. 2010; 18: 52-62. 